\title{
Adsorption of strontium and caesium onto an Na-MX80 bentonite: experiments and building of a coherent thermodynamic modelling
}

\author{
Brice Siroux ${ }^{1}$, Catherine Beaucaire ${ }^{2}$, Michel Tabarant, ${ }^{1}$ Marc F. Benedetti ${ }^{3}$, Pascal E. Reiller*1 \\ ${ }^{1}$ Den - Service d'Études Analytiques et de Réactivité des Surfaces (SEARS), CEA, Université Paris-Saclay, F- \\ 91191, Gif-sur-Yvette, France \\ 2 Den - Service d'Études du Comportement des Radionucléides (SECR), CEA, Université Paris-Saclay, F-91191, \\ Gif-sur-Yvette, France \\ ${ }^{3}$ Institut de Physique du Globe de Paris, Sorbonne Paris Cité, Université Paris Diderot, UMR 7154 CNRS, F- \\ 75005 Paris, France \\ *Corresponding author. Tel.: +33 16908 4312; fax: +33 16908 9475. E-mail address: pascal.reiller@cea.fr (P.E. \\ Reiller)
}

\section{http://doi.org/10.1016/j.apgeochem.2017.10.022}

\section{Abstract}

Multi-site ion exchange modelling permits describing the different adsorption behaviour of cations onto clay minerals. Considering several adsorption sites in the clay minerals' structure allows accurately representing the overall variations of adsorption behaviours. For a wider applicability in soils and sediments, it appears necessary to build a coherent thermodynamic adsorption database for radionuclides. ${ }^{90} \mathrm{Sr}$ and ${ }^{134,137} \mathrm{Cs}$ are major radionuclides to be considered in the case of nuclear accidents, but thermodynamic data on their adsorption on purified smectites are scarce. Therefore, a detailed study to determine $\mathrm{Sr}^{2+}$ and $\mathrm{Cs}^{+}$adsorption parameter on smectite seems necessary. To provide this kind of information, this study is proposing multi-site ion exchange modelling of the adsorption of $\mathrm{Sr}^{2+}$ and $\mathrm{Cs}^{+}$onto a pure Na-MX80 montmorillonite. The intrinsic parameters-site concentration and corrected selectivity coefficient for the $\mathrm{Na}^{+} / \mathrm{H}^{+}$exchange-were first fitted using an already available Na saturation curve of a purified smectite. The adsorption of $\mathrm{Sr}^{2+}$ and $\mathrm{Cs}^{+}$on a purified $\mathrm{Na}-\mathrm{MX} 80$ bentonite was explored, including a kinetic study for $\mathrm{Sr}$, as a function of $\mathrm{pH}$ and equilibrium concentration. The isotherms were modelled to determine the corrected selectivity coefficients for the $2 \mathrm{Na}^{+} / \mathrm{Sr}^{2+}$ and $\mathrm{Na}^{+} / \mathrm{Cs}^{+}$exchange reactions. This study provides a part of a wider databasis that is currently under construction, which can be used to predict the adsorption of Sr and Cs in soils and sediments. 


\section{Introduction}

With the use and development of nuclear energy, the knowledge of the behaviour of the ${ }^{235} \mathrm{U}$ daughters in the environment is essential and has widely been studied. ${ }^{90} \mathrm{Sr}$ and ${ }^{137} \mathrm{Cs}$, with half-lives of 29 and 30 years, respectively, are amongst the major by-products from the fission of ${ }^{235} \mathrm{U}$ (England and Rider, 1993). These isotopes were spread in the environment after the fall-out of the different nuclear weapon detonations, and after the nuclear accidents at Chernobyl (IAEA, 2006) and Fukushima-Daiichi (Sahoo et al., 2016). Because of its capacity to substitute with calcium in the food chain, ${ }^{90} \mathrm{Sr}$ can disturb ecological systems (Comar et al., 1957). Concerning ${ }^{137} \mathrm{Cs}$, it is considered as a dangerous element because its high sol to plant transfer and radioactive decay includes ${ }^{137} \mathrm{Ba}$ and its gamma radiation.

Strontium and caesium are known to be greatly adsorbed onto soils, more specifically by clay minerals as illite (Bilgin et al., 2001) or kaolinite (Erten et al., 1988; Galamboš et al., 2013). If illite and vermiculite are known to be the strongest adsorbents for caesium, particularly due to the presence of the low concentration of high affinity frayed edge sites (Brouwer et al., 1983; Dzene et al., 2015; Sawhney, 1972), montmorillonite could also play an important role in the adsorption of $\mathrm{Sr}$ and $\mathrm{Cs}$ due to its high cationic exchange capacity (CEC).

The study of the adsorption behaviour of Sr onto pure Na-montmorillonite has been mainly led on smectite-rich soils (Galamboš et al., 2010; Kasar et al., 2014) or non-purified bentonite (Wang et al., 2004). Studies on purified smectite remain scarce in the literature. Missana and García-Gutiérrez (2007) have worked on a purified Na-FEBEX bentonite, which contains illite-smectite interstratified layers that provide specific fixation sites for $\mathrm{Cs}^{+}$or $\mathrm{K}^{+}$. Thereby, FEBEX bentonite cannot be considered as a pure smectite. Nevertheless, the similarity of the adsorption behaviour of Sr onto illite and smectite (Missana et al., 2008) could permit comparing these results with those obtained on purified smectite.

Only a few papers deal with Cs adsorption onto pure Na-montmorillonite. As for Sr, most of these works deal with smectite-rich soils (Vejsada et al., 2005), non-purified (Galamboš et al., 2010; Montavon et al., 2006; Wang et al., 2010) or not mono-ionic conditioned bentonite (Wu et al., 2009). Gorgeon (1994) reported trace $\mathrm{Cs}^{+}$adsorption onto a pure Na-saturated Wyoming montmorillonite in $1 \mathrm{~mol}$ per $\mathrm{kg}$ of water $\left(\mathrm{mol} \cdot \mathrm{kg}_{\mathrm{w}}{ }^{-1}\right) \mathrm{NaCl}$. As the ionic strength is well outside the validity domain of the Davies (1962) equation, they will not be included in our discussion. As the specific interaction parameter $\varepsilon\left(\mathrm{Cs}^{+}, \mathrm{Cl}-\right)$ is not available, and in view of the specific $\log _{10} \gamma_{ \pm, \mathrm{CsCl}}$ Vs. $m_{\mathrm{CsCl}}$ variation (Hamer and $\mathrm{Wu}, 1972$ ), a complete refitting using the specific interaction theory (Ciavatta, 1980) would be necessary, which is out of the framework of this study. This data can only be used as qualitative comparison. Missana et al. (2014a) studied the adsorption of caesium onto an Na-FEBEX bentonite, which carries a significant part of interstratified illite-smectite (vide ante). The illite part from these interstratified is well known to show specific adsorption behaviour towards $\mathrm{Cs}^{+}$partly due to the FES. As explained in Ogasawara et al. (2013), even a slight proportion of illite in clay minerals tends to drive the adsorption of $\mathrm{Cs}^{+}$at trace level and prevents the direct 
comparison between the results of Missana et al. (2014a) with results that could be obtained on purified smectite. Even at high concentration of Cs, illite could dominates the adsorption, as shown by Missana et al. (2014b) in San Juan clay (illite, smectite, kaolinite mixture).

The adsorption onto bentonite, as for many clay minerals (Carroll, 1959), is mainly controlled by an ion-exchange mechanism. Semi-empirical approaches of these adsorption mechanisms onto bentonite were used (Dyer et al., 2000; Guimarães et al., 2015; Mahoney and Langmuir, 1991; Rafferty et al., 1981; Shaban and Macášek, 1998), but few works used a mechanistic, or semi-mechanistic, approach. Bradbury and Baeyens (1999) have developed a model based on a mechanistic description of the cation adsorption between a clay minerals and a liquid phase-namely the two-site protolysis non-electrostatic surface complexation and cation exchange model or 2SPNE SC/CE. This model is combining both cation exchange reactions based on the Gaines and Thomas (1953) formalism-with no account for the $\mathrm{Na}^{+} / \mathrm{H}^{+}$ exchange-, and non-electrostatic surface complexation terms. Missana et al. (2008) applied a model derived from 2SPNE-SC/CE to study the adsorption of $\mathrm{Sr}^{2+}$ onto illite, smectite, and illite/smectite mixtures. This approach allows representing the global adsorption behaviour. Within the framework of this model, the $\mathrm{pH}$ dependency is given by the adsorption on edge sites $>\mathrm{S}-\mathrm{OH}$-either silanol or aluminols sites. Adsorption onto cation exchange sites is not $\mathrm{pH}$ dependent. Conversely, adsorption of electrolyte cations only occurs on cation exchange sites. From their basic hypotheses these models do not allow modelling the saturation of a homo-ionic exchanger by a major cation, e.g. the $\mathrm{Na}^{+} / \mathrm{H}^{+}$exchange all over the $\mathrm{pH}$ range. Conversely, within the multi-site ion exchange modelling framework the $\mathrm{Na}^{+} / \mathrm{H}^{+}$exchange is considered intrinsically, as well as the exchange between a metal cation and $\mathrm{Na}^{+}$or $\mathrm{H}^{+}$ exchange (Gaucher, 1998; Gorgeon, 1994; Motellier et al., 2003; Nolin, 1997; Peynet, 2003; Reinoso-Maset and Ly, 2014; Stammose et al., 1992).

In this study, a multi-site ion exchange modelling has been used. This model is based on the ion exchange theory (Tremillon, 1965) and has been developed to represent the adsorption processes on clay minerals (Gaucher, 1998; Gorgeon, 1994; Motellier et al., 2003; Nolin, 1997; Peynet, 2003; Reinoso-Maset and Ly, 2014; Stammose et al., 1992), mixtures of minerals (Peynet, 2003), or soils (Jacquier et al., 2004). The model does not aim to describe clay minerals at the microscopic scale-nature of adsorption sites, particularly affectation of sites defined by the model to the FES sites, surface charge, etc.-but takes into account the adsorption behaviour of major and trace elements in order to represent clay mineral characteristics. The model considers clay minerals as multi-site ion exchangers that bear negative adsorption sites $\left(\mathrm{X}_{\mathrm{i}}^{-}\right)$in contact with the solution. The exchanger(s) and the aqueous solution are considered as non-miscible phases. Each site $i$ can potentially adsorb any cation. It is defined by a site concentration ( $\mathrm{SC}_{\mathrm{i}}$ in mmol per $\mathrm{g}$ of exchanger), and a corrected-of adsorbed species activity coefficient-selectivity coefficient for the exchange reaction between cations, e.g. $\mathrm{K}_{\mathrm{Na}^{+} / \mathrm{H}^{+}}$for the $\mathrm{Na}^{+} / \mathrm{H}^{+}$exchange. 
This approach requires a careful and thorough characterisation of adsorption. First, the ion exchange properties ( $\mathrm{SC}_{\mathrm{i}}$ and corrected selectivity coefficients) have to be measured in a wide parametric domain of $\mathrm{pH}$, ionic strength, and metal concentration (Jacquier et al., 2004; Motellier et al., 2003; Reinoso-Maset and Ly, 2014; Robin et al., 2015; Stammose et al., 1992), forming a coherent thermodynamic database for adsorption. All the exchange properties are experimentally measurable with adsorption isotherms. Afterwards, these properties can be used to study the metal adsorption (Tertre et al., 2009), or diffusion (Lu et al., 2014; Savoye et al., 2012), in different mineral contexts.

In order to continue building a coherent database, including Sr and Cs, and in light of the few amount of data on the adsorption of these cations onto pure smectite, the aim of this paper is first to ascertain the exchange properties of smectite- $\mathrm{SC}_{\mathrm{i}}$ and corrected selectivity coefficient for the $\mathrm{Na}^{+} / \mathrm{H}^{+}$exchange-, and second to acquire experimental data on the adsorption of $\mathrm{Sr}^{2+}$ and $\mathrm{Cs}^{+}$on a homo-ionic pure smectite-here the MX80 bentonite-as a function of $\mathrm{pH}$, ionic strength, and initial concentration of cations. Then, the isotherms will be fitted using multi-site ion exchange modelling to determine the corrected selectivity coefficients for the $2 \mathrm{Na}^{+} / \mathrm{Sr}^{2+}$ and $\mathrm{Na}^{+} / \mathrm{Cs}^{+}$exchange reactions. The overall objective is to propose a coherent set of data for describing the adsorption behaviour of $\mathrm{Na}^{+}, \mathrm{H}^{+}, \mathrm{Sr}^{2+}$, and $\mathrm{Cs}^{+}$on a pure smectite. This set of data could then be used to predict the adsorption of $\mathrm{Sr}$ and Cs in Na-rich soils.

\section{Materials and methods}

\subsection{Materials}

Wyoming MX80 bentonite was used as the adsorbent. It was purified to keep only the montmorillonite part, and conditioned under Na-saturated form following protocols in Gaucher (1998) and Peynet (2003). The organic matter potentially present in the material was removed using $\mathrm{H}_{2} \mathrm{O}_{2}$ at $80{ }^{\circ} \mathrm{C}$, and calcite was dissolved using $0.1 \mathrm{M} \mathrm{HCl}$ solution. The montmorillonite was Na-conditioned by several washings using a $1 \mathrm{M} \mathrm{NaCl}$ solution. The reported CEC for the MX80 varies from 0.71 to $1.03 \mathrm{mmol}^{-1} \mathrm{~g}^{-1}$ (Alonso and Ledesma, 2005; Karnland, 2010; Meier, 1999). This value depends upon the measurement protocol or the sample purity. A CEC of 1.03 mmol.g- ${ }^{-1}$ was measured for this MX80, extracting all exchangeable cations with a $\mathrm{KCl}$ solution at $\mathrm{pH}$ ca. $10(\mathrm{KOH})$. Supernatant was removed and the MX80 was washed with milli-Q water, then with ethanol. The adsorbed $\mathrm{K}^{+}$cations were extracted with a $\mathrm{CsCl}$ solution, and analysed by inductively coupled plasma atomic emission spectroscopy (ICP-AES). This high CEC value tends to confirm the high purity of the montmorillonite extracted from the MX80 bentonite. The purity was also confirmed by X-ray crystallography (XRG 3000, Inel) - see Fig. A1 of the Appendices. Moreover, the material only presents traces of exchangeable $\mathrm{K}$ and $\mathrm{Mg}$ (less than 1\%) and is Na-saturated.

The chemicals used were at least of analytical grade. Stable $\mathrm{Sr}$ solutions were prepared from a $\mathrm{SrCl}_{2} \cdot 6 \mathrm{H}_{2} \mathrm{O}$ salt (99.995\% trace metals basis, Sigma Aldrich). Stable Cs solutions were from 
$\mathrm{CsCl}$ (99.999\% trace metals basis, Sigma Aldrich). ${ }^{85} \mathrm{Sr}$ and ${ }^{137} \mathrm{Cs}$ solutions were obtained from Cerca LEA. Ionic strength was fixed using $\mathrm{NaCl}$ (Analar Normapur, VWR).

\subsection{Adsorption experiments}

\subsubsection{Experimental protocols}

All experiments were performed by batch method at room temperature $\left(22 \pm 2^{\circ} \mathrm{C}\right)$ with the same 3.8 g.L $\mathrm{L}^{-1}$ solid/solution ratio. Polycarbonate Nalgene centrifuge tube $(10 \mathrm{~mL}, 3138$ 0010, Thermo Scientific) were used. All the solutions and suspensions were made by weighing.

In all experiments the MX80 bentonite was first equilibrated under agitation with the $\mathrm{NaCl}$ electrolyte for $24 \mathrm{~h}$. The $\mathrm{pH}$ values were adjusted with $1,0.1$ or $0.01 \mathrm{~mol}_{\mathrm{kg}} \mathrm{w}^{-1}$ solutions of $\mathrm{HCl}$ or $\mathrm{NaOH}$, and suspension were left under agitation for $24 \mathrm{~h}$. A total concentration of stable strontium $-1.510^{-5} \mathrm{~mol} \mathrm{~kg}_{\mathrm{w}}{ }^{-1}$ of $\mathrm{SrCl}_{2}$ for the kinetic experiment, $10^{-6} \mathrm{~mol} . \mathrm{kg}_{\mathrm{w}}{ }^{-1}$ for the adsorption of Sr vs. $\mathrm{pH}$, and from $10^{-2}$ to $10^{-7} \mathrm{~mol}^{-\mathrm{kg}_{\mathrm{w}}}{ }^{-1}$ for the adsorption of $\mathrm{Sr}$ as a function of the concentration-or Cs $\left(10^{-7} \mathrm{~mol}_{\mathrm{kg}} \mathrm{kg}^{-1}\right)$ was added from the stock solution, and the suspensions were then spiked with ${ }^{85} \mathrm{Sr}$ or ${ }^{137} \mathrm{Cs}$ (ca. 3,000 Bq) and left under agitation-1 day for Sr studies and 2 days for Cs study from the kinetic experiment, vide infra. Finally, the suspensions were ultra-centrifuged (70.1 Ti Rotor, Optima LE-80R, Beckman) during 30 minutes at 9,000 g; $1 \mathrm{~mL}$ aliquots of the supernatant were collected, and activity was counted by gamma spectrometry.

A set of kinetic experiments was also prepared without the ${ }^{85} \mathrm{Sr}$ spiking. Mixtures were left under agitation from 0 to 4 days and the equilibrium concentrations were analysed by ICPAES.

The initial activities in the spiked experiments were determined using a blank procedure same protocol but without Na-MX80 montmorillonite in batches. The partition coefficients $\mathrm{R}_{\mathrm{D}}\left(\mathrm{L} . \mathrm{kg}^{-1}\right)$ were calculated using:

$$
R_{D}=\left(\frac{C^{\circ}}{C_{e q}}-1\right) \cdot \frac{V}{m}
$$

where $\mathrm{C}^{\circ}$ and $\mathrm{C}_{\mathrm{eq}}$ are respectively the initial and equilibrium concentrations (kinetic experiments) or activities ( $\mathrm{pH}$ and concentration isotherms) of either Sr or Cs, $V$ is the total volume of solution (L) and $m$ is the total dry mass of solid phase (kg).

\subsubsection{Analytical methods}

The aqueous concentrations of inactive $\mathrm{Sr}$ and $\mathrm{Na}$ in solutions were measured by ICP-AES (Activa, Horiba Jobin Yvon). Samples were diluted with 2\% sub-boiling $\mathrm{HNO}_{3}$ (DuoPur, Milestone). Measurements were made with five points calibration curves at $407.771 \mathrm{~nm}$ for strontium and $589.592 \mathrm{~nm}$ for sodium. The aqueous concentrations of inactive Cs in solution 
were determined by inductively coupled plasma mass spectrometry (ICP-MS, Element 2, Thermo Scientific).

Supernatant activities of ${ }^{85} \mathrm{Sr}$ and ${ }^{137} \mathrm{Cs}$ were determined after sampling of $1 \mathrm{~mL}$ aliquots using a gamma counter (1480 Wizard 3, Perkin Elmer). The $\mathrm{pH}$ values were measured with a combined microelectrode ( $\mathrm{pH}$ InLab, Mettler Toledo) by redetermination of the potential/pH plot of the electrode, and by calculating the value of the solutions from their potentials (buffer solutions 4.01, 7.00, 9.18, Merck). Uncertainties from the linear regression are typically in the range of 0.05 units of $\mathrm{pH}$.

\subsection{Modelling}

The competitive adsorption onto clays is described by a multi-site ion exchange model. This model is detailed in the Appendices and only the main expressions are recalled here without demonstration. First, the adsorption of major cations $-\mathrm{Na}^{+}$in this study-is studied vs. $\mathrm{pH}$ on a homoionic conditioned montmorillonite under Na-saturation conditions. The evolution of the retention of $\mathrm{Na}^{+}$as a function of $\mathrm{pH}$ is measured in order to describe the exchanger in terms of site concentrations and corrected selectivity coefficients for $\mathrm{Na}^{+} / \mathrm{H}^{+}$exchange $\left(\mathrm{K}_{\mathrm{Na}^{+} / \mathrm{H}^{+}}^{* \dot{3}}\right)$. In an aqueous solution containing only $\mathrm{Na}^{+}$and $\mathrm{H}^{+}$, the equilibrium of a given negatively charge type of site $\mathrm{X}_{\mathrm{i}}^{-}$saturated with $\mathrm{Na}^{+}$from the montmorillonite with the solution is described by the following equilibrium.

$$
\overline{\mathrm{X}_{1}^{-}-\mathrm{Na}^{+}}+\mathrm{H}^{+} \rightleftarrows \overline{\mathrm{X}_{1}^{-}-\mathrm{H}^{+}}+\mathrm{Na}^{+}
$$

The corresponding corrected selectivity coefficient of this equilibrium can be written as,

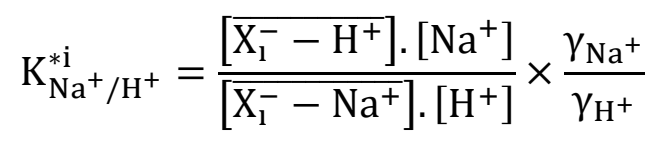

where [ ] is the solution (mol. $\mathrm{kg}^{-1}$ of water) concentration, [-] is the adsorbed concentration (mol.kg- ${ }^{-1}$ of solid) of species, and $\gamma$ are the activity coefficient of aqueous species-calculated here using Davies (1962) equation.

Each type of site $i$ is also described by a site concentration $\mathrm{SC}_{\mathrm{i}}$ in mol.kg-1 of solid. The sum of the $\mathrm{SC}_{\mathrm{i}}$ is equal to the sum of all the adsorbed species concentrations.

$$
\mathrm{SC}_{\mathrm{i}}=\left[\overline{\mathrm{X}_{1}^{-}-\mathrm{H}^{+}}\right]+\left[\overline{\mathrm{X}_{1}^{-}-\mathrm{Na}^{+}}\right]
$$

The methodology to study the saturation of an exchanger with a major cation is detailed elsewhere (Motellier et al., 2003; Reinoso-Maset and Ly, 2014; Stammose et al., 1992).

To determine the corrected selectivity coefficients for the exchange between the trace $\left(\mathrm{Cs}^{+}\right.$ and $\mathrm{Sr}^{2+}$ ) and major $\left(\mathrm{Na}^{+}\right)$cations, the retention is studied on a homoionic sodic conditioned montmorillonite vs. the solution $\mathrm{pH}$ and the equilibrium concentration of the trace cation. 
The corrected selectivity coefficient of a cation $\mathrm{M}^{\mathrm{m}+}$ with regards to $\mathrm{Na}^{+}$can be written as follows.

$$
\mathrm{K}_{\mathrm{mNa}}^{* \mathrm{i}} / \mathrm{M}^{\mathrm{m}+}=\frac{\left[\overline{\left(\mathrm{X}_{1}^{-}\right)_{\mathrm{m}}-\mathrm{M}^{\mathrm{m}+}}\right] \cdot\left[\mathrm{Na}^{+}\right]^{\mathrm{m}} \cdot \gamma_{\mathrm{Na}^{+}}^{\mathrm{m}}}{\left[\overline{\mathrm{X}_{1}^{-}-\mathrm{Na}^{+}}\right]^{\mathrm{m}} \cdot\left[\mathrm{M}^{\mathrm{m}+}\right] \cdot \gamma_{\mathrm{M}^{\mathrm{m}}}}
$$

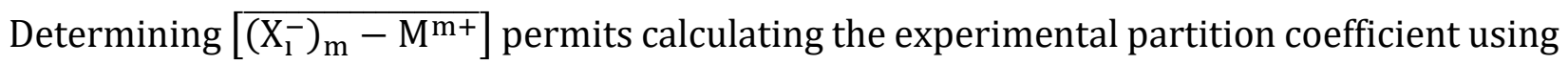
the following expression.

$$
R_{D}=\frac{[\overline{\mathrm{M}}]}{[M]}=\frac{\sum_{i}\left[\overline{\left.\left(\mathrm{X}_{1}^{-}\right)_{\mathrm{m}}-\mathrm{M}^{\mathrm{m}+}\right]}\right.}{[M]}
$$

The methodology to study the adsorption of a trace element onto a homo-ionic exchanger is also detailed elsewhere (Jacquier et al., 2004; Tertre et al., 2009).

The different site concentrations and corrected selectivity coefficients were obtained fitting the theoretical expression to the experimental data using the MS Excel Solver. The uncertainties of these parameters were obtained using the SolverAid macro from De Levie (2004).

\section{Results and discussion}

\subsection{Preliminary remarks}

In this study, MX80 bentonite was supposed to be fully Na-saturated. Despite their possible interactions in the adsorption process, other exchangeable cation, e.g. $\mathrm{Ca}^{2+}$ and $\mathrm{K}^{+}$present in the exchanger (cf. § 2.1), were neglected. Their trace level concentrations were supposed to be low enough not to interfere in experimental results. Furthermore, the possible dissolution of smectite was not considered either. It is known that $\mathrm{pH}<4$ or $\mathrm{pH}>10$ the dissolution of clay minerals can be important (Amram and Ganor, 2005; Bradbury and Baeyens, 1997). The dissolution can lead to a release of aluminium, silicon, iron, and other structural cations as $\mathrm{K}^{+}$ and $\mathrm{Mg}^{2+}$. The release of these ions-mainly $\mathrm{Al}(\mathrm{OH})_{\mathrm{n}}(3-\mathrm{n})+$ or $\mathrm{Fe}(\mathrm{OH})_{\mathrm{n}}(3-\mathrm{n})+$ - could compete with the adsorption of $\mathrm{Sr}^{2+}$ and $\mathrm{Cs}^{+}$in MX80. Then, the account of these phenomena is very difficult to manage, see e.g. Bradbury and Baeyens (2005). Hence, one must not forget that these phenomena are intrinsically included into the corrected selectivity coefficients. The deconvolution of these phenomena would require a dedicated study of the clay minerals' structure with $\mathrm{pH}$, and according modifications of the exchangers.

\subsection{Selection of the adsorption parameters of the exchanger}

The initial parameters of the exchanger $\left(\mathrm{SC}_{\mathrm{i}}\right.$ and $\log _{10} \mathrm{~K}_{\mathrm{Na}^{+} / \mathrm{H}^{+}}^{* \mathrm{i}}$ ) are determined by fitting the saturation curve of a homo-ionic Na-exchanger at varying $\mathrm{pH}$. The saturation of a montmorillonite with $\mathrm{Na}^{+}$has been already studied by Gorgeon (1994), Nolin (1997), and Peynet (2003): Gorgeon (1994) considered only one major site $S_{1}$ with a concentration of 0.422 mmol.g-1; Peynet (2003) reported two major sites $\left(\Sigma \mathrm{SC}_{\mathrm{i}}=0.605 \mathrm{mmol.g}{ }^{-1}\right)$; and Nolin 
(1997) proposed three sites $\left(\Sigma \mathrm{SC}_{\mathrm{i}}=0.886 \mathrm{mmol}^{-1}\right)^{-1}$. The saturation study from Nolin (1997) is the only one that reached a total site concentration close to the typical montmorillonite CEC (Bradbury and Baeyens, 1997; Staunton and Roubaud, 1997). The montmorillonite used by Gorgeon (1994) was not completely saturated with $\mathrm{Na}^{+}$and bared remaining $\mathrm{Ca}^{2+}$. It has been reported by Nolin (1997), and resumed by Tertre et al. (2009), that the remaining $\mathrm{Ca}^{2+}$ could compete with the adsorption of $\mathrm{Na}^{+}$and distort the Na saturation curve. Compared to Gorgeon (1994) and Nolin (1997), the montmorillonite from Peynet (2003) was less pure, i.e., $80 \%$ for Peynet (2003), 98\% for Gorgeon (1994), and 96\% for Nolin (1997). Thus, the saturation curve obtained by Nolin (1997) was chosen and reinterpreted in the framework of the multi-site ion exchange model, as done by others authors (Lu et al., 2014; Robin et al., 2015; Savoye et al., 2015; Tertre et al., 2009; Tertre et al., 2011; Tertre et al., 2013).

The saturation curve obtained by Nolin (1997) is presented in Fig. 1. The adsorbed concentration of $\mathrm{Na}^{+}$is increasing with $\mathrm{pH}$ until 4.5. Then, the adsorption remains practically constant until another increase at $\mathrm{pH}$ 9.5. From this saturation curve, three waves are observable. These waves can represent the saturation of the different fixation sites of the exchanger. As previously explained, in the $\mathrm{pH}$ range $2-4$, the low adsorption of $\mathrm{Na}^{+}$is possibly due to the competition with $\mathrm{H}^{+}$but also with other cations released from the smectite dissolution.

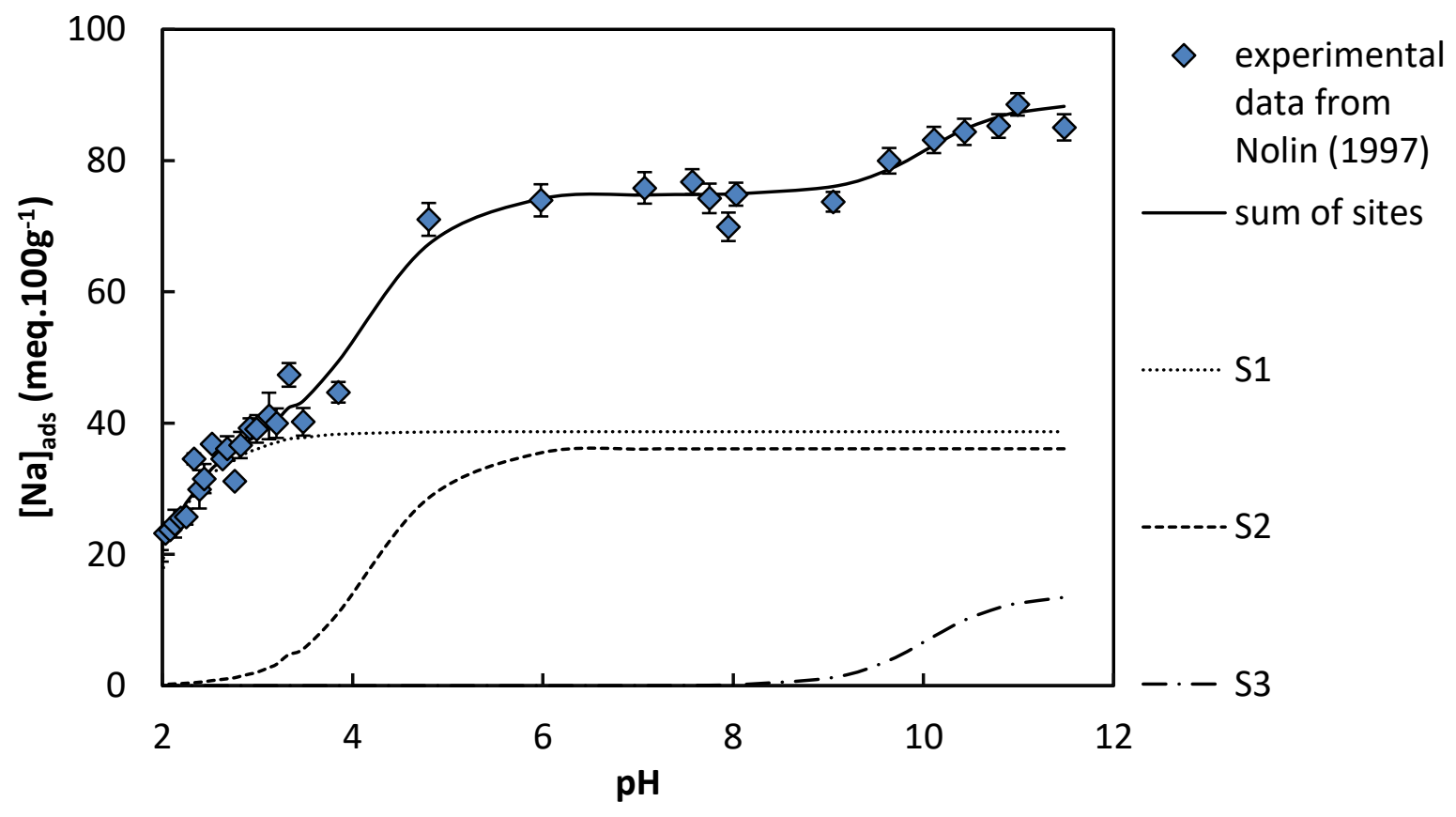

Fig. 1. Modelling of the saturation of a montmorillonite with $\mathrm{Na}^{+} v$ s. $\mathrm{pH}$ at constant $\mathrm{I}=0.02 \mathrm{M}$ $\left(\mathrm{NaClO}_{4}\right)$ and solid/liquid ratio $(\mathrm{S} / \mathrm{L})$ of $8 \mathrm{~g} \cdot \mathrm{L}^{-1}$, and modelling (plain line) with sites $\mathrm{S}_{1}$ (dotted line), $S_{2}$ (dotted line), and $S_{3}$ (dash-dotted line) from Nolin (1997). 
Nolin (1997) calculated the corrected selectivity coefficients for the $\mathrm{Na}^{+} / \mathrm{H}^{+}$exchange for his smectite, but the reported uncertainties were unexpectedly high $(>40 \%$ relative uncertainty) compared to the correlation with the saturation curve. As the fitting protocol of $\log _{10} \mathrm{~K}_{\mathrm{Na}^{+} / \mathrm{H}^{+}}^{* \mathrm{a}}$ and uncertainties estimations were not given, we propose a new fitting of these data in Fig. 1. The site concentrations from Nolin (1997) and the obtained $\log _{10} \mathrm{~K}_{\mathrm{Na}^{+} / \mathrm{H}^{+}}$are summarized in Table 1 . The sum of $\mathrm{SC}_{\mathrm{i}}$ is supposed to be close to the $\mathrm{CEC}$, but in this particular case, the $\Sigma \mathrm{SC}_{\mathrm{i}}$ is lower than the measured CEC for the MX80. Dissimilarities in used materials-SWy-1 in Nolin (1997) vs. MX80 in this study-could explain the differences. With the aim of proposing a general database for montmorillonite, the value of $0.886 \mathrm{mmol.g}$ 1 seems in good agreement with those proposed by different authors for a Wyoming montmorillonite (Bradbury and Baeyens, 1997; Staunton and Roubaud, 1997).

Table 1. Site concentrations and corrected selectivity coefficients for the $\mathrm{Na}^{+} / \mathrm{H}^{+}$exchange onto a montmorillonite.

\begin{tabular}{c|cc|c}
\hline Site & $\mathbf{S C}_{\mathbf{i}}\left(\mathbf{m m o l . g} \mathbf{- 1}^{-1}\right)$ & $\begin{array}{c}\boldsymbol{\Sigma} \mathbf{C C}_{\mathbf{i}}(\mathbf{m m o l . g} \\
\mathbf{1})\end{array}$ & $\log _{\mathbf{1 0}} \boldsymbol{K}_{\mathbf{N a}^{+} / \mathbf{H}^{+}}^{* i}$ \\
\hline $\mathbf{S}_{\mathbf{1}}$ & $0.387 \pm 0.038^{\mathrm{a}}$ & & $0.24 \pm 0.04$ \\
$\mathbf{S}_{\mathbf{2}}$ & $0.361 \pm 0.068^{\mathrm{a}}$ & 0.887 & $2.62 \pm 0.08$ \\
$\boldsymbol{S}_{\mathbf{3}}$ & $0.139 \pm 0.092^{\mathrm{a}}$ & & $8.45 \pm 0.18$ \\
\hline
\end{tabular}

a site concentrations taken from Nolin (1997)

\subsection{Strontium adsorption}

Multiple facets of the strontium adsorption onto the Na-saturated MX80 montmorillonite were explored in this study. The kinetics of adsorption has been examined to determine the necessary equilibrium time. The adsorption behaviour of $\mathrm{Sr}^{2+}$ as a function of the equilibrium $\mathrm{pH}$ and the Sr concentrations were studied building adsorption isotherms. The role of the ionic strength was also examined. With the aim of building a coherent set of data, all corrected selectivity coefficients of the $2 \mathrm{Na}^{+} / \mathrm{Sr}^{2+}$ exchange reactions were adjusted to match the adsorption isotherms as a function of the equilibrium $\mathrm{pH}$, ionic strength, and the $\mathrm{Sr}$ concentration.

The $\mathrm{Sr}^{2+}$ cation is the main $\mathrm{Sr}$ specie in solution in all these experiments- $\mathrm{SrCl}^{+}$represents $3 \%(\mathrm{I}=0.15 \mathrm{M}), 2 \%(\mathrm{I}=0.1 \mathrm{M})$ and $1 \%(\mathrm{I}=0.05 \mathrm{M})$ of the dissolved species (Sverjensky et al., 1997), and $\mathrm{SrOH}^{+}$is not significantly present in solution below pH 10 (Shock et al., 1997). Nevertheless, all the speciation effects are taken into consideration in the modelling (cf. Appendix B.2)

\subsubsection{Kinetic experiments}

Fig. 2 shows the adsorption kinetics ( $\mathrm{R}_{\mathrm{D}}$ as a function of the contact time) of Sr onto the NaMX80. The equilibrium is reached within minutes. The $R_{D}$ value is constant all through the experiment with an average value of $R_{D}=(192 \pm 35)$ L.kg-1. 
In similar experiments Galamboš et al. (2013) have studied the kinetic of adsorption of $\mathrm{Sr}^{2+}$ onto three different bentonite samples. They showed that the equilibrium was achieved within 10 seconds, and the adsorption remained constant during at least 10 days, which is in agreement with our results. In our case, the final equilibrium time between bentonite $/ \mathrm{NaCl}$ mixture and the strontium solution was set at 12 hours to be sure to achieve the equilibrium.

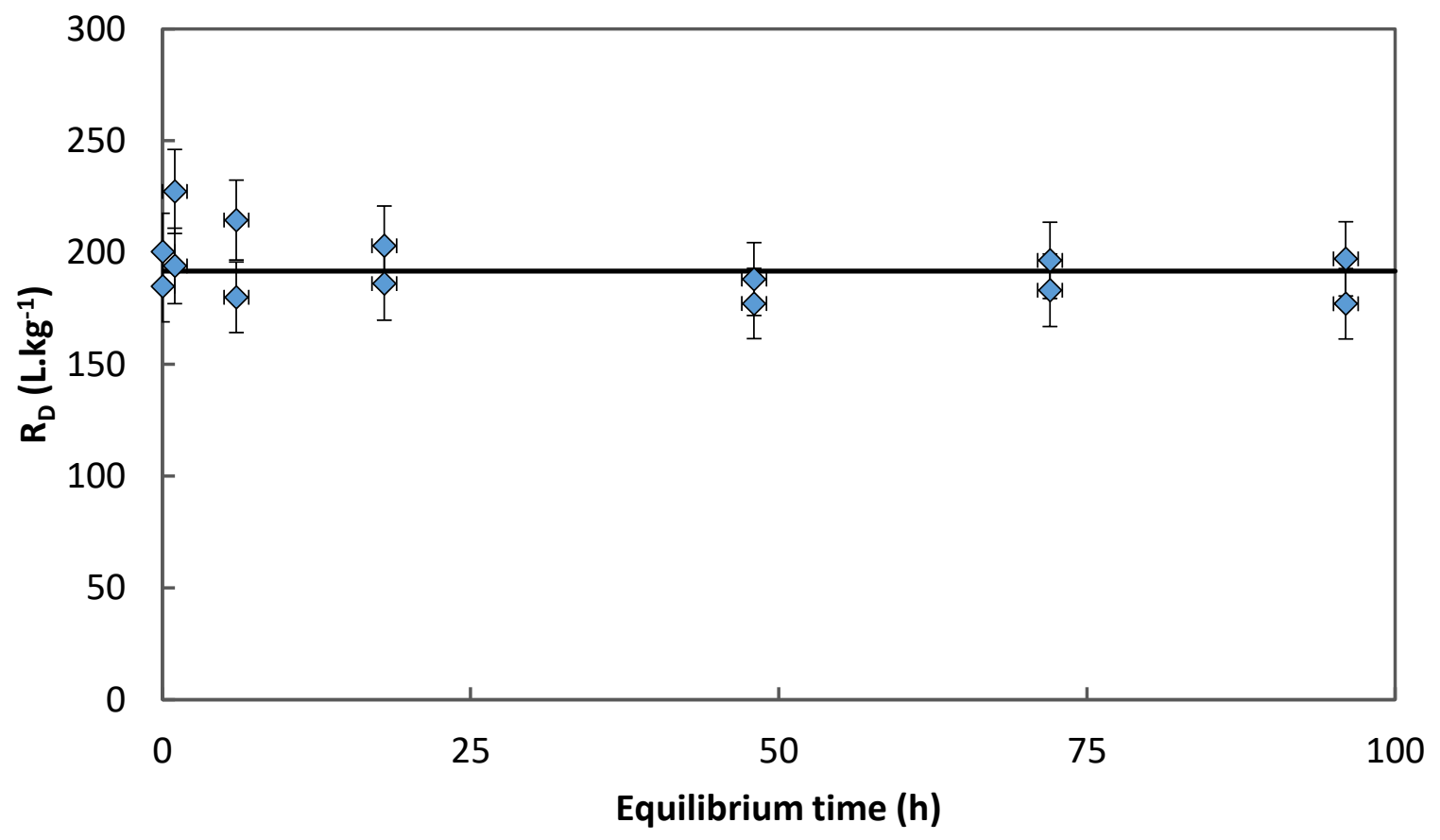

Fig. 2. Kinetic study of the adsorption at $[\mathrm{Sr}]$ total $=1.510^{-5} \mathrm{~mol}_{\mathrm{kg}} \mathrm{w}^{-1}, \mathrm{pH}=7, I=0.1 \mathrm{mol.} \mathrm{kg}_{w^{-1}}$ ( $\mathrm{NaCl}$ ) and $S / L=3.8 \mathrm{~g} \cdot \mathrm{L}^{-1}$-time 0 is corresponding to the centrifugation time (30 $\mathrm{min}$ ) without prior agitation.

\subsubsection{Adsorption experiments and modelling}

Fig. 3 shows the adsorption isotherm of Sr vs. pH onto the Na-MX80 at two ionic strengths,

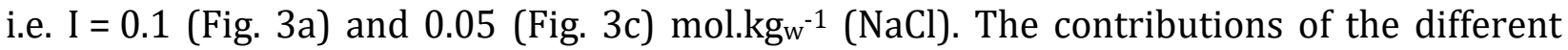
adsorption sites are also represented. At $\mathrm{I}=0.1 \mathrm{~mol} \cdot \mathrm{kg}_{\mathrm{w}}{ }^{-1}$, the adsorption steadily increases with $\mathrm{pH}$. At $\mathrm{I}=0.05 \mathrm{~mol} \cdot \mathrm{kg}_{\mathrm{w}}{ }^{-1}$, the evolution of $\mathrm{R}_{\mathrm{D}}$ is also influenced by $\mathrm{pH}$. The $\mathrm{R}_{\mathrm{D}}$ increases gradually up to $\mathrm{pH} 7$ then reaches a plateau. It is worthy to note that Sr adsorption is decreasing with increasing ionic strength as expected for an ion exchange mechanism. 

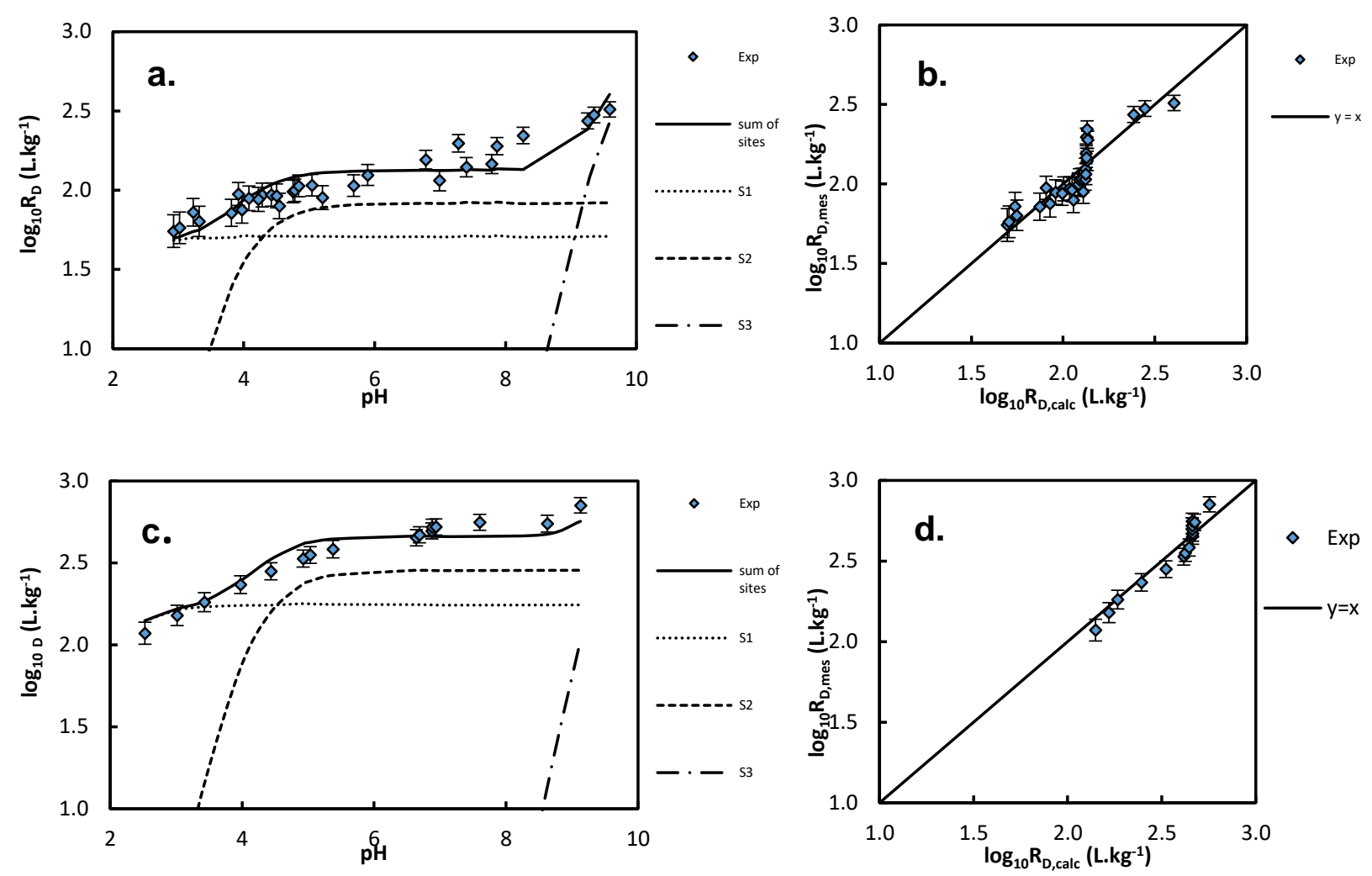

Fig. 3. Adsorption isotherms of $[\mathrm{Sr}]_{\text {total }}=10^{-6} \mathrm{~mol}^{\mathrm{kg}} \mathrm{k}^{-1}$ as a function of $\mathrm{pH}$, and comparison of experimental with modelling results at $S / L=3.8 \mathrm{~g} \cdot \mathrm{L}^{-1}$ and $I=0.1 \mathrm{~mol} \cdot \mathrm{kg}_{w^{-1}}(\mathrm{NaCl})(a, b)$ and $I=$ 0.05 mol. $\mathrm{kg}_{w^{-1}}(\mathrm{NaCl})(\mathrm{c}, \mathrm{d})$; representation of the contribution of the differents fixation sites, $S_{1}$ in dotted lines, $S_{2}$ in dashed lines, and $S_{3}$ in dash-dotted lines.

The concentration isotherm as a function of the equilibrium concentration at $0.15 \mathrm{~mol}_{\mathrm{kg}} \mathrm{kg}_{\mathrm{w}}{ }^{-1}$ $\mathrm{NaCl}$ and fixed $\mathrm{pH}=6.6$ is shown in Fig. 4a. Strontium adsorption weakly depends on initial concentrations and does not seem to present any specific behaviour. The isotherm is nearly linear in the range $[\mathrm{Sr}]_{\mathrm{eq}}=10^{-7}-10^{-4} \mathrm{~mol}_{\mathrm{kg}} \mathrm{kg}^{-1}\left(\log _{10} \mathrm{R}_{\mathrm{D}}=2.1\right)$ then decreases at the highest concentrations, due to the saturation of the clay mineral. 

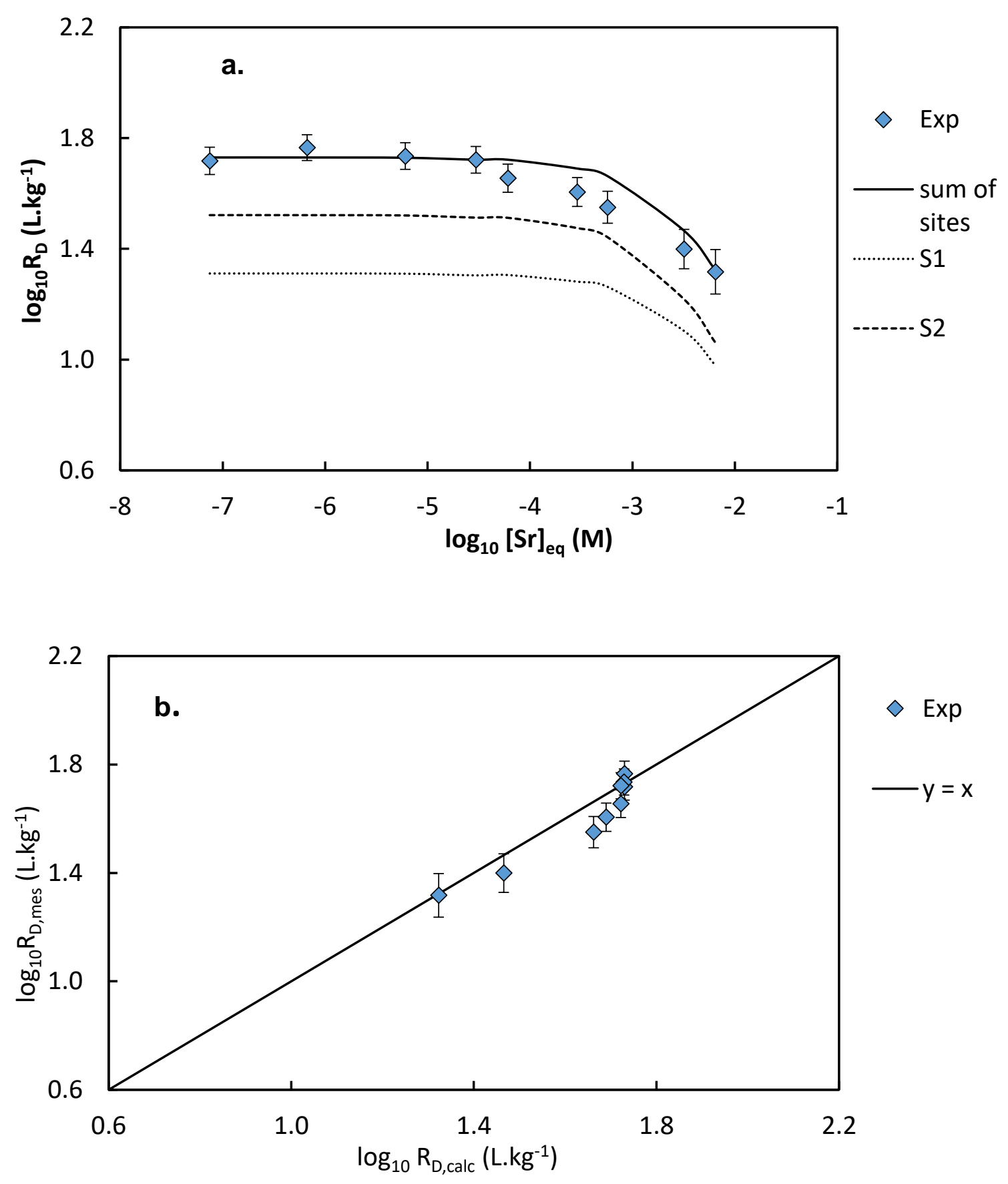

Fig. 4. Adsorption isotherm in concentration of $\mathrm{Sr}$ on MX80 bentonite at $I=0.15 \mathrm{~mol} . \mathrm{kg}_{w^{-1}}$ (NaCl), $p H=6.6$ and and $S / L=3.8 \mathrm{~g} \cdot \mathrm{L}^{-1}$, and representation of the influence of the differents exchange sites (a)-the $S_{3}$ site does not appear onto the isotherm because of its minor contribution-; and comparison of the experimental with the modelling results (b). 
The site concentrations from Nolin (1997) and $\log _{10} \mathrm{~K}_{\mathrm{Na}^{+} / \mathrm{H}^{+}}^{* \mathrm{i}}$ in Table 1 were chosen to

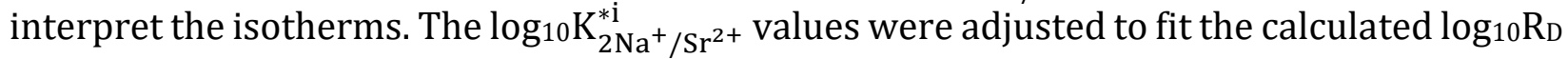
values to the experimental ones.

Table 2. Obtained parameters of the corrected selectivity coefficients for $2 \mathrm{Na}^{+} / \mathrm{Sr}^{2+}$ and $\mathrm{Na}^{+} / \mathrm{CS}^{+}$ exchange. Values from Missana and García-Gutiérrez (2007) are recalculated within the framework of the multi-site ion exchange model (see Appendices for details).

\begin{tabular}{|c|c|c|c|c|c|}
\hline References & & $\mathrm{SC}_{\mathrm{i}}\left(\mathrm{mmol} . \mathrm{g}^{-1}\right)$ & 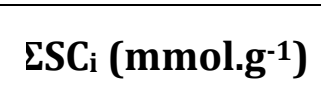 & $\log _{10} \mathrm{~K}_{2 \mathrm{Na}^{+} / \mathrm{Sr}^{2}}^{* \mathrm{i}}$ & $\log _{10} \mathrm{~K}_{\mathrm{Na}^{+} / \mathrm{Cs}}^{* \mathrm{i}}$ \\
\hline This study & $\begin{array}{l}S_{1} \\
S_{2} \\
S_{3}\end{array}$ & $\begin{array}{l}0.387 \pm 0.038^{a} \\
0.361 \pm 0.068^{a} \\
0.139 \pm 0.092^{a}\end{array}$ & 0.886 & $\begin{array}{l}0.73 \pm 0.03 \\
1.00 \pm 0.03 \\
2.92 \pm 0.08\end{array}$ & $\begin{array}{l}1.57 \pm 0.02 \\
0.98 \pm 0.13 \\
0.69 \pm 0.32\end{array}$ \\
\hline $\begin{array}{c}\text { Missana and } \\
\text { García- } \\
\text { Gutiérrez } \\
\text { (2007) }\end{array}$ & $\begin{array}{l}S_{1} \\
S_{2} \\
S_{3}\end{array}$ & & .02 & $\begin{array}{l}0.77 \\
0.80 \\
1.22\end{array}$ & \\
\hline
\end{tabular}

a values from Nolin (1997)

Modelling of strontium adsorption is represented in Fig. 3 and Fig. 4. The modelling

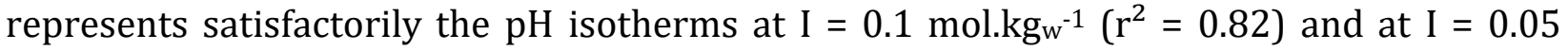
mol. $\mathrm{kg}_{\mathrm{w}}{ }^{-1}\left(\mathrm{r}^{2}=0.90\right)$, and the concentration isotherm $\left(\mathrm{r}^{2}=0.86\right)$. As the modelling strongly depends on the initial parameters used $\left(\mathrm{SC}_{\mathrm{i}}\right.$ and $\mathrm{K}_{\mathrm{Na}^{+} / \mathrm{H}^{+}}^{\mathrm{i}}$ ), modelling results cannot be improved without modifying these initial parameters. The choice of adjusting simultaneously all isotherms constrained the modelling, but enhances its applicability at different ionic strengths. For each isotherm, by using the previously discussed initial parameters, it appears that only the first two sites would be influent to describe $\mathrm{Sr}$ adsorption in the $\mathrm{pH}$ range 2.59, and in the Sr concentration range $10^{-7}-10^{-2} \mathrm{~mol}^{-\mathrm{kg}_{\mathrm{w}}}{ }^{-1}$ at $\mathrm{pH} 6.6$.

The obtained corrected selectivity coefficients for the $2 \mathrm{Na}^{+} / \mathrm{Sr}^{2+}$ exchange can be compared with existing literature. Missana and García-Gutiérrez (2007) studied the adsorption of Sr onto a FEBEX bentonite at different ionic strengths. These experiments were described using a model derived from the one proposed by Bradbury and Baeyens (1999). At I $=0.05$ and 0.1 mol. $\mathrm{kg}_{\mathrm{w}}{ }^{-1}$ Missana and García-Gutiérrez (2007) obtained slightly higher $\log _{10} \mathrm{R}_{\mathrm{D}}$ values compared to our study $-\log _{10} R_{D}(0.1 \mathrm{M})=2.16$ and $\log _{10} \mathrm{R}_{\mathrm{D}}(0.05 \mathrm{M})=2.82$ for Missana and García-Gutiérrez (2007) against $\log _{10} \mathrm{RD}_{\mathrm{D}}\left(0.1 \mathrm{~mol}_{\mathrm{kg}} \mathrm{kg}^{-1}\right)=2.12$ and $\log _{10} \mathrm{RD}_{\mathrm{D}}\left(0.05 \mathrm{~mol} \cdot \mathrm{kg}_{\mathrm{w}}{ }^{-1}\right)=$

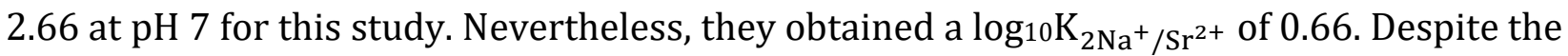
fact that they used a different model, it is possible to compare their selectivity coefficient with 
the ones obtained here. If the selectivity coefficients from Missana and García-Gutiérrez (2007) are transformed according to our multi-site formalism - see Appendices for details, the parameters are comparable (cf. Table 2), except for $\mathrm{S}_{3}$. As this transformation implies the site concentrations, and as Missana and García-Gutiérrez (2007) have used a bentonite with a CEC higher than our sum of site concentrations, this transformation only serves to compare the orders of magnitude.

As mentioned in the introduction, the slight difference in parameters can come from the bentonite used by Missana and García-Gutiérrez (2007), as the FEBEX bentonite includes a significant part of illite-smectite mixed layers, and as illite and smectite have comparable but yet different selectivity for $\mathrm{Sr}$ (Missana et al., 2004). The differences in the selectivity coefficients could also arise from the intrinsic properties of used bentonites, as their specific surface areas.

\subsection{Caesium adsorption}

The adsorption behaviour of caesium was explored as a function of $\mathrm{pH}$ to determine the corrected selectivity coefficients $\mathrm{K}_{\mathrm{Na}^{+} / \mathrm{Cs}^{+}}^{*}$. The adsorption of $\mathrm{Cs}^{+}$onto montmorillonite seems to quickly reach the equilibrium according to $\mathrm{Wu}$ et al. (2009) who reported that the adsorption equilibrium of Cs onto montmorillonite mineral is achieved after 5 minutes of contact time. Therefore, the adsorption kinetics has not been explored in this study. The equilibrium time used was the same as for $\mathrm{Sr}$.

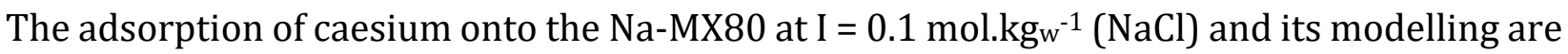
shown in Fig. 5. As for $\mathrm{Sr}^{2+}$, the $\mathrm{Cs}^{+}$adsorption is weakly dependent on the equilibrium $\mathrm{pH}$. The adsorption increases up to $\mathrm{pH} 5$, then seems to stay constant. The $\log _{10} \mathrm{R}_{\mathrm{D}}$ value at this

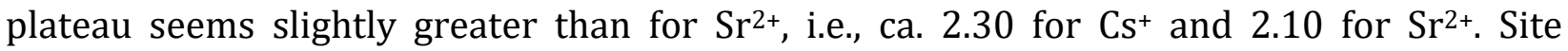
concentrations from Nolin (1997) and corrected selectivity coefficients for the $\mathrm{Na}^{+} / \mathrm{H}^{+}$ exchange in Table 2 were used to model the isotherm and to determine the corrected selectivity coefficients of the $\mathrm{Na}^{+} / \mathrm{Cs}^{+}$exchange. Due to the weak variation in adsorption, the $\mathrm{S}_{1}$ and $\mathrm{S}_{2}$ sites seem to mainly drive the variation of $\mathrm{Cs}^{+}$adsorption in the $\mathrm{pH}$ range, while the $\mathrm{S}_{3}$ site is only needed at high $\mathrm{pH}$ and does not greatly contribute to the representation of the adsorption behaviour. This phenomenon explains the high uncertainty of $\log _{10} \mathrm{~K}_{\mathrm{Na}^{+}}^{* 3} / \mathrm{Cs}^{+}$ (around 50\%). 

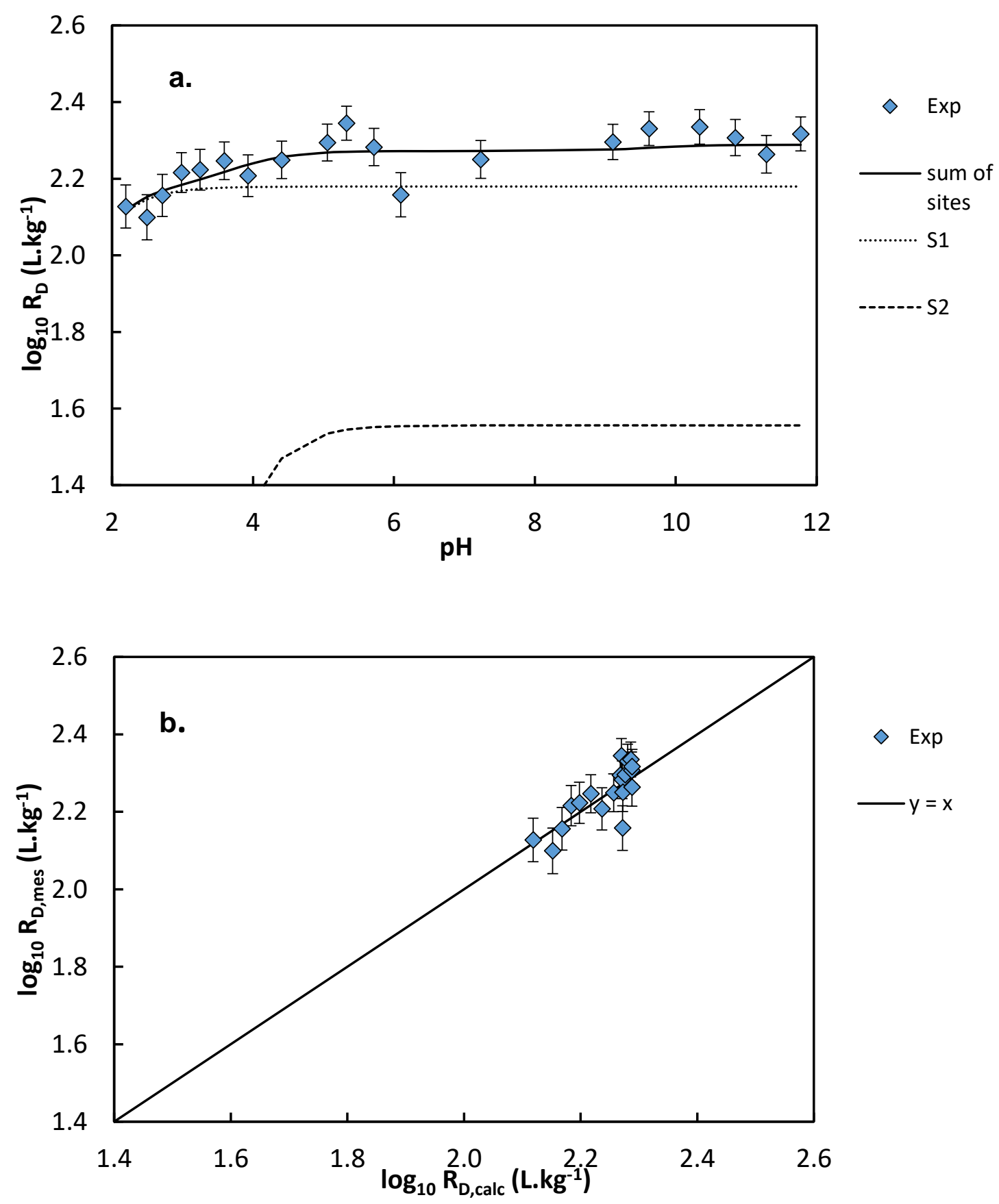

Fig. 5. Adsorption isotherms of $[\mathrm{Cs}]_{i}=10^{-7} \mathrm{~mol} \mathrm{kgw}^{-1} \mathrm{vs}$. $\mathrm{pH}$ at $\mathrm{I}=0.1 \mathrm{~mol} . \mathrm{kg}_{w^{-1}}(\mathrm{NaCl})$ and $\mathrm{S} / \mathrm{L}=$ $3.8 \mathrm{~g} \cdot \mathrm{L}^{-1}$ on a Na-MX80 bentonite and representation of the contribution of the different fixation sites (a) and comparison of the experimental to the modelling results (b).

As explained earlier, the great variability of protocol in the literature on the adsorption of Cs onto montmorillonite impedes comparisons between the different results obtained onto 
non-purified or not Na-conditioned bentonite (Galamboš et al., 2010; Montavon et al., 2006; Vejsada et al., 2005; Wang et al., 2010). Only Missana et al. (2014a) used a purified Naconditioned bentonite, but the significant part of interstratified smectite/illite from this bentonite prevents the comparison with our study owing to the very strong and specific adsorption behaviour of caesium onto illite (Ogasawara et al., 2013). This could explain the difference in $\log _{10} \mathrm{~K}_{\mathrm{D}}$ between Missana et al. (2014a) - $\log _{10} \mathrm{~K}_{\mathrm{D}}$ viz. 3.2 at $\mathrm{C}_{\text {eq }} \approx 10^{-7} \mathrm{M}, \mathrm{I}=0.1$ $\mathrm{M} \mathrm{NaClO}_{4}$ and $\mathrm{pH}$ 6.5-and the $\log _{10} \mathrm{~K}_{\mathrm{D}}=2.3$ in Fig. 5a.

\section{Conclusions}

The adsorption behaviour of Sr and Cs on a purified Na-MX80 bentonite was studied, with the objective to determine the corrected selectivity coefficients of the $2 \mathrm{Na}^{+} / \mathrm{Sr}^{2+}$ and $\mathrm{Na}^{+} / \mathrm{Cs}^{+}$ exchanges using the multi-site ion exchange formalism. The site repartitions and concentrations of the Na-MX80 montmorillonite were taken from literature (Nolin, 1997), and corrected selectivity coefficients for the $\mathrm{Na}^{+} / \mathrm{H}^{+}$exchange were obtained from a new fit.

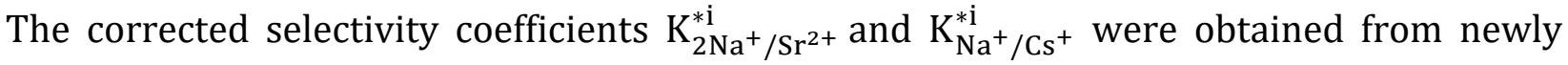
acquired $\mathrm{pH}$ and concentration isotherms onto an Na-MX80 montmorillonite, in coherence with the site capacities determined by Nolin (1997), and corrected selectivity coefficient $\mathrm{K}_{\mathrm{Na}^{+} / \mathrm{H}^{+}}^{* \mathrm{f}}$ itted in this study.

Some parameters were neglected in this work; traces of exchangeable cations still remains in the Na-MX80. Their concentrations were supposed low enough not to impact the adsorption of $\mathrm{H}^{+}, \mathrm{Na}^{+}, \mathrm{Cs}^{+}$, and $\mathrm{Sr}^{2+}$. Moreover, the possible dissolution of smectite at acidic or alkaline $\mathrm{pH}$-leading to a release of exchangeable cation $\mathrm{K}^{+}, \mathrm{Mg}^{2+}, \mathrm{Al}^{3+}$, etc. - was not taken into account. These phenomena may affect the adsorption behaviour in different ways: (i) decrease of the fixation sites concentrations; (ii) modification of the clay minerals structure; and (iii) adsorption competition between the different cations. One can come to the conclusion that these three phenomena are contained-and not directly expressed-in the corrected selectivity coefficients. Thus, obtained experimental points and associated modelling at $\mathrm{pH}$ below 4 and above 10 could be taken with caution, and a more dedicated study on the account of the clay dissolution, and hence of exchanger properties modifications at low and high $\mathrm{pH}$, could be needed.

Nonetheless, this study can serve as a part of a thermodynamic adsorption database to predict the adsorption of radionuclides, including $\mathrm{Sr}^{2+}$ and $\mathrm{Cs}^{+}$, onto mixtures of clay minerals. The inclusion of $\mathrm{Ca}^{2+}$ and $\mathrm{K}^{+}$as other major cations in clayey environments will be the next step to more fully describe the adsorption behaviour of these radionuclides onto soils or sediments.

\section{Acknowledgment}

This work was financed through the French "Programme Investissement d'Avenir" (ANR-11RSNR-0005 DEMETERRES). An anonymous reviewer is acknowledged for his helpful suggestions. Dr Thomas Gimmi is acknowledged for his editorial handling. 


\section{References}

Alonso, E.E., Ledesma, A., 2005. Advances in Understanding Engineered Clay Barriers: Proceedings of the International Symposium on Large Scale Field Tests in Granite. Taylor \& Francis.

Amram, K., Ganor, J., 2005. The combined effect of $\mathrm{pH}$ and temperature on smectite dissolution rate under acidic conditions. Geochim. Cosmochim. Acta 69, 2535-2546.

Bilgin, B., Atun, G., Keçeli, G., 2001. Adsorption of strontium on illite. J. Radioanal. Nucl. Chem. 250, 323-328.

Bradbury, M.H., Baeyens, B., 1997. A mechanistic description of $\mathrm{Ni}$ and $\mathrm{Zn}$ sorption on $\mathrm{Na}$ montmorillonite Part II: modelling. J. Contam. Hydrol. 27, 223-248.

Bradbury, M.H., Baeyens, B., 1999. Modelling the sorption of $\mathrm{Zn}$ and $\mathrm{Ni}$ on Ca-montmorillonite. Geochim. Cosmochim. Acta 63, 325-336.

Bradbury, M.H., Baeyens, B., 2005, Experimental and Modelling Investigations on Na-Illite: AcidBase behaviour and the Sorption of Strontium, Nickel, Europium and Uranyl. Paul Scherrer Institute, Villigen, Switzerland. Report PSI Bericht 05-02. $\quad$ pp. 73. http://www.iaea.org/inis/collection/NCLCollectio nStore/_Public/36/111/36111078.pdf.

Brouwer, E., Baeyens, B., Maes, A., Cremers, A., 1983. Cesium and rubidium ion equilibria in illite clay. J. Phys. Chem. 87, 1213-1219.

Carroll, D., 1959. Ion exchange in clays and other minerals. Geol. Soc. Am. Bull. 70, 749-779.

Ciavatta, L., 1980. The specific interaction theory in evaluating ionic equilibria. Ann. Chim. (Roma) 70, 551-567.

Comar, C.L., Russell, R.S., Wasserman, R.H., 1957. Strontium-calcium movement from soil to man. Science 126, 485-492.

Davies, C.W., 1962. Ion association. Butterworths.

De Levie, R., 2004. Advanced Excel for Scientific Data Analysis. Oxford University Press. pp. 638. http://books.google.fr/books?id=IAnO-2qVazsC.
Dyer, A., Chow, J.K.K., Umar, I.M., 2000. The uptake of caesium and strontium radioisotopes onto clays. J. Mater. Chem. 10, 2734-2740.

Dzene, L., Tertre, E., Hubert, F., Ferrage, E., 2015. Nature of the sites involved in the process of cesium desorption from vermiculite. J. Colloid Interface Sci. $455,254-260$

England, T.R., Rider, B.F., 1993, ENDF-349 Evaluation and Compilation of Fission Product Yields. Lawrence Berkeley National Laboratory. Report LA-UR-3106. pp. 173. http://t2.lanl.gov/nis/publications/endf349.pdf.

Erten, H.N., Aksoyoglu, S., Hatipoglu, S., Gokturk, H., 1988. Sorption of cesium and strontium on montmorillonite and kaolinite. Radiochim. Acta $44 / 45,147-151$.

Gaines, G.L., Thomas, H.C., 1953. Adsorption studies on clay minerals. II. A formulation of the thermodynamics of exchange adsorption. J. Chem. Phys. 21, 714-718.

Galamboš, M., Krajnak, A., Rosskopfová, O.g., Viglasova, E., Adamcova, R., Rajec, P., 2013. Adsorption equilibrium and kinetic studies of strontium on Mg-bentonite, Fe-bentonite and illite/smectite. J. Radioanal. Nucl. Chem. 298, 10311040.

Galamboš, M., Kufčáková, J., Rosskopfová, O.g., Rajec, P., 2010. Adsorption of cesium and strontium on natrified bentonites. J. Radioanal. Nucl. Chem. 283, 803-813.

Gaucher, E., 1998. Interactions eaux-argiles. Etude expérimentale. PhD Thesis. Université Denis Diderot (Paris VII), Paris, France. pp. 260. In French.

Gorgeon, L., 1994. Contribution à la modélisation physico-chimique de la rétention de radioéléments à vie longue par des matériaux argileux. PhD Thesis. Université Pierre et Marie Curie (Paris VI), Paris, France. pp. 189. In French.

Guimarães, V., Azenha, M., Rocha, F., Silva, F., Bobos, I., 2015. Influence of $\mathrm{pH}$, concentration and ionic strength during batch and flow-through continuous stirred reactor experiments of $\mathrm{Sr}^{2+}$-adsorption onto 
montmorillonite. J. Radioanal. Nucl. Chem. 303, 2243-2255.

Hamer, W.J., Wu, Y.C., 1972. Osmotic coefficients and mean activity coefficients of uni-univalent electrolytes in water at $25^{\circ} \mathrm{C}$. J. Phys. Chem. Ref. Data $1,1047-1100$.

IAEA, 2006. Environmental Consequences of the Chernobyl Accident and their Remediation: Twenty Years of Experience. Report of the Chernobyl Forum Expert Group 'Environment'. International Atomic Energy Agency Vienna, Austria. pp. 166. http://www-

pub.iaea.org/MTCD/publications/PDF/Pub1239_ web.pdf.

Jacquier, P., Ly, J., Beaucaire, C., 2004. The ionexchange properties of the Tournemire argillite - I. Study of the $\mathrm{H}, \mathrm{Na}, \mathrm{K}, \mathrm{Cs}, \mathrm{Ca}$ and $\mathrm{Mg}$ behaviour. Appl. Clay Sci. 26, 163-170.

Karnland, O., 2010, Chemical and Mineralogical Characterization of the Bentonite Buffer for the Acceptance Control Procedure in a KBS-3 Repository. SKB, Stockholm, Sweden. Report TR10-60.

http://www.skb.se/upload/publications/pdf/TR10-60.pdf.

Kasar, S., Kumar, S., Kar, A., Bajpai, R.K., Kaushik, C.P., Tomar, B.S., 2014. Retention behaviour of $\mathrm{Cs}(\mathrm{I}), \mathrm{Sr}(\mathrm{II}), \mathrm{Tc}(\mathrm{VII})$ and $\mathrm{Np}(\mathrm{V})$ on smectite-rich clay. J. Radioanal. Nucl. Chem. 300, 71-75.

Lu, J., Tertre, E., Beaucaire, C., 2014. Assessment of a predictive model to describe the migration of major inorganic cations in a Bt soil horizon. Appl. Geochem. 41, 151-162.

Mahoney, J.J., Langmuir, D., 1991. Adsorption of Sr on kaolinite, illite and montmorillonite at high ionic strengths. Radiochim. Acta 54, 139-144.

Meier, P.L., 1999. Determination of the cation exchange capacity (CEC) of clay minerals using the complexes of copper(II) Ion with triethylenetetramine and tetraethylenepentamine. Clays Clay Miner. 47, 386-388.

Missana, T., Benedicto, A., García-Gutiérrez, M., Alonso, U., 2014a. Modeling cesium retention onto Na-, K- and Ca-smectite: effects of ionic strength, exchange and competing cations on the determination of selectivity coefficients. Geochim. Cosmochim. Acta 128, 266-277.

Missana, T., García-Gutiérrez, M., 2007. Adsorption of bivalent ions (Ca(II), Sr(II) and $\mathrm{Co}(\mathrm{II})$ ) onto FEBEX bentonite. Phys. Chem. Earth 32, 559-567.

Missana, T., García-Gutiérrez, M., Alonso, U., 2004. Kinetics and irreversibility of cesium and uranium sorption onto bentonite colloids in a deep granitic environment. Appl. Clay Sci. 26, 137-150.

Missana, T., García-Gutiérrez, M., Alonso, U., 2008. Sorption of strontium onto illite/smectite mixed clays. Phys. Chem. Earth 33, S156-S162.

Missana, T., García-Gutiérrez, M., Benedicto, A., Ayora, C., De-Pourcq, K., 2014b. Modelling of Cs sorption in natural mixed-clays and the effects of ion competition. Appl. Geochem. 49, 95-102.

Montavon, G., Alhajji, E., Grambow, B., 2006. Study of the interaction of $\mathrm{Ni}^{2+}$ and $\mathrm{Cs}^{+}$on $\mathrm{MX}-80$ bentonite; effect of compaction using the "capillary method". Environ. Sci. Technol. 40, 4672-4679.

Motellier, S., Ly, J., Gorgeon, L., Charles, Y., Hainos, D., Meier, P., Page, J., 2003. Modelling of the ionexchange properties and indirect determination of the interstitial water composition of an argillaceous rock. Application to the Callovo-Oxfordian lowwater-content formation. Appl. Geochem. 18, 15171530.

Nolin, D., 1997. Rétention de radioéléments à vie longue par des matériaux argileux - Influence d'anions contenue dans les eaux naturelles. PhD Thesis. Université Pierre et Marie Curie (Paris VI), Paris, France. pp. 221. In French.

Ogasawara, S., Nakao, A., Yanai, J., 2013. Radiocesium interception potential (RIP) of smectite and kaolin reference minerals containing illite (micaceous mineral) as impurity. Soil Sci. Plant Nutr. 59, 852-857.

Peynet, V., 2003. Retention d'actinide et de produits de fission par des phases solides polyminerales. PhD Thesis. Université Pierre et Marie Curie (Paris VI), Paris, France. pp. 273. In French.

Rafferty, P., Shiao, S.Y., Binz, C.M., Meyers, R.E., 1981. Adsorption of Sr(II) on clay-minerals: effects of salt concentration, loading, and pH. J. Inorg. Nucl. Chem. 43, 797-805. 
Reinoso-Maset, E., Ly, J., 2014. Study of major ions sorption equilibria to characterize the ion exchange properties of kaolinite. J. Chem. Eng. Data 59, 40004009.

Ringböm, A., 1963. Complexation in Analytical Chemistry: A Guide for the Critical Selection of Analytical Methods Based on Complexation Reactions. Interscience Publishers, New York, NY, USA. pp. 395.

Robin, V., Tertre, E., Beaufort, D., Regnault, O., Sardini, P., Descostes, M., 2015. Ion exchange reactions of major inorganic cations $\left(\mathrm{H}^{+}, \mathrm{Na}^{+}, \mathrm{Ca}^{2+}\right.$, $\mathrm{Mg}^{2+}$ and $\mathrm{K}^{+}$) on beidellite: experimental results and new thermodynamic database. Toward a better prediction of contaminant mobility in natural environments. Appl. Geochem. 59, 74-84.

Sahoo, S.K., Kavasi, N., Sorimachi, A., Arae, H., Tokonami, S., Mietelski, J.W., Łokas, E., Yoshida, S., 2016. Strontium-90 activity concentration in soil samples from the exclusion zone of the Fukushima daiichi nuclear power plant. Sci. Rep. 6, 23925.

Savoye, S., Beaucaire, C., Fayette, A., Herbette, M., Coelho, D., 2012. Mobility of cesium through the Callovo-Oxfordian claystones under partially saturated conditions. Environ. Sci. Technol. 46, 2633-2641.

Savoye, S., Beaucaire, C., Grenut, B., Fayette, A., 2015. Impact of the solution ionic strength on strontium diffusion through the Callovo-Oxfordian clayrocks: an experimental and modeling study. Appl. Geochem. 61, 41-52.

Sawhney, B.L., 1972. Selective sorption and fixation of cations by clay minerals: a review. Clays Clay Miner. 20, 93-100.

Shaban, I.S., Macášek, F., 1998. Influence of humic substances on sorption of cesium and strontium on montmorillonite. J. Radioanal. Nucl. Chem. 229, 7378.

Shock, E.L., Sassani, D.C., Willis, M., Sverjensky, D.A., 1997. Inorganic species in geologic fluids: Correlations among standard molal thermodynamic properties of aqueous ions and hydroxide complexes. Geochim. Cosmochim. Acta 61, 907-950.
Stammose, D., Ly, J., Pitsch, H., Dolo, J.-M., 1992. Sorption mechanisms of three actinides on a clayey mineral. Appl. Clay Sci. 7, 225-238.

Staunton, S., Roubaud, M., 1997. Adsorption of ${ }^{137}$ Cs on montmorillonite and illite: effect of charge compensating cation, ionic strength, concentration of Cs, K and fulvic acid. Clays Clay Miner. 45, 251260.

Sverjensky, D.A., Shock, E.L., Helgeson, H.C., 1997. Prediction of the thermodynamic properties of aqueous metal complexes to $1000^{\circ} \mathrm{C}$ and $5 \mathrm{~kb}$. Geochim. Cosmochim. Acta 61, 1359-1412.

Tertre, E., Beaucaire, C., Coreau, N., Juery, A., 2009. Modelling $\mathrm{Zn}(\mathrm{II})$ sorption onto clayey sediments using a multi-site ion-exchange model. Appl. Geochem. 24, 1852-1861.

Tertre, E., Ferrage, E., Bihannic, I., Michot, L.J., Prêt, D., 2011. Influence of the ionic strength and solid/solution ratio on $\mathrm{Ca}$ (II)-for- $\mathrm{Na}^{+}$exchange on montmorillonite. Part 2: Understanding the effect of the $m / V$ ratio. Implications for pore water composition and element transport in natural media. J. Colloid Interface Sci. 363, 334-347.

Tertre, E., Hubert, F., Bruzac, S., Pacreau, M., Ferrage, E., Pret, D., 2013. Ion-exchange reactions on clay minerals coupled with advection/dispersion processes. Application to $\mathrm{Na}^{+} / \mathrm{Ca}^{2+}$ exchange on vermiculite: reactivetransport modeling, batch and stirred flow-through reactor experiments. Geochim. Cosmochim. Acta 112, 1-19.

Tremillon, B., 1965. Les Séparations par les Résines Échangeuses d'Ions. Gauthier-Villars, Paris, France. pp. 400.

Vejsada, J., Jelínek, E., Řanda, Z., Hradil, D., Přikryl, R., 2005. Sorption of cesium on smectite-rich clays from the Bohemian Massif (Czech Republic) and their mixtures with sand. Appl. Radiat. Isot. 62, 9196.

Wang, T.-H., Hsieh, C.-J., Lin, S.-M., Wu, D.-C., Li, M.H., Teng, S.-P., 2010. Effect of alkyl properties and head groups of cationic surfactants on retention of cesium by organoclays. Environ. Sci. Technol. 44, 5142-5147.

Wang, X., Chen, Y., Wu, Y., 2004. Sorption and desorption of radiostrontium on powdered 
bentonite: effect of $\mathrm{pH}$ and fulvic acid. J. Radioanal. Nucl. Chem. 261, 497-500.

Wu, J.J., Li, B., Liao, J.L., Feng, Y., Zhang, D., Zhao, J., Wen, W., Yang, Y.Y., Liu, N., 2009. Behavior and analysis of cesium adsorption on montmorillonite mineral. J. Environ. Radioact. 100, 914-920. 


\section{Appendices}

The appendices contain the XRD diffractogram of the purified Na-MX80 and the development of the modelling formalism.

\section{A. XRD diffractogram of Na-MX80}

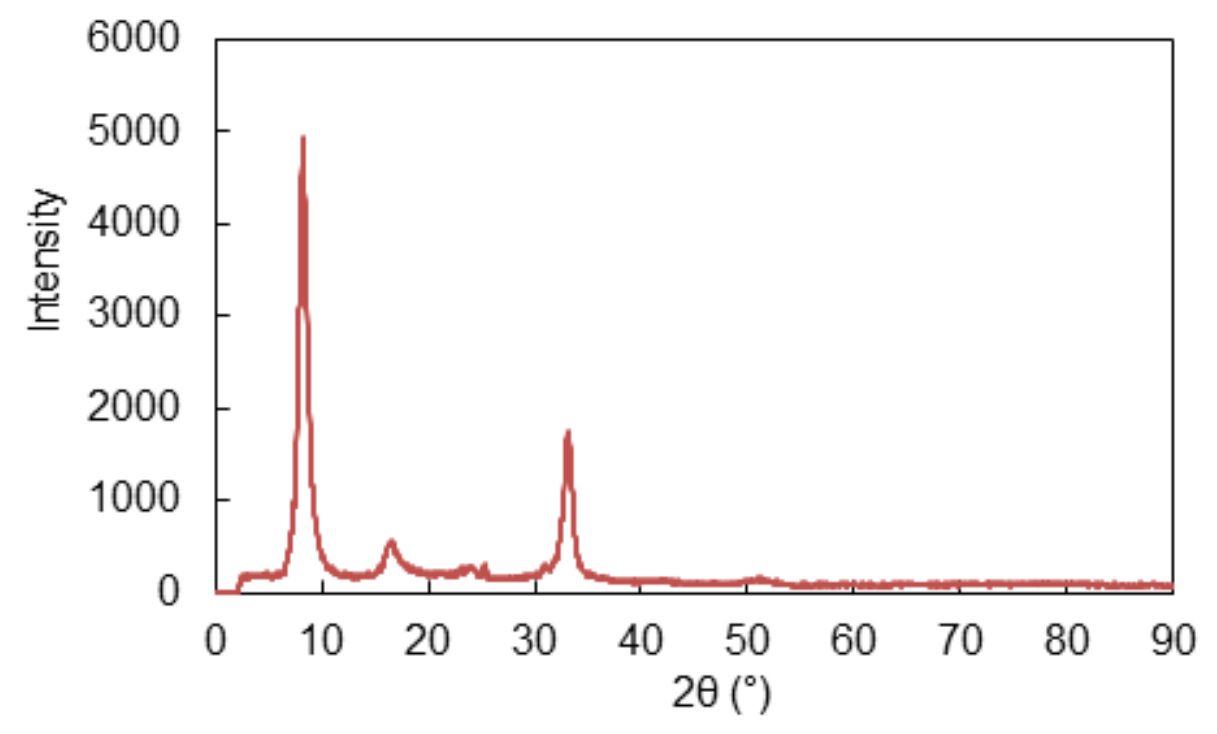

Fig. A1. XRD powder diffractogram of the purified Na-MX80

\section{B. Modelling formalism}

\section{B.1 Saturation curves}

The competitive adsorption onto clays is described by a multi-site ion exchange model. The exchange reaction between $\mathrm{Na}^{+}$and $\mathrm{H}^{+}$in a Na-saturated exchanger can be expressed as follows, where $\mathrm{X}_{\mathrm{i}}^{-}$is a given type of negatively charged site $i$,

$$
\overline{\mathrm{X}_{1}^{-}-N a^{+}}+\mathrm{H}^{+}=\overline{\mathrm{X}_{1}^{-}-H^{+}}+N a^{+}
$$

with the corresponding equilibrium constant,

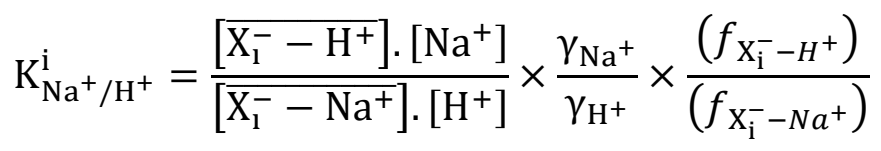


where [ ] is the solution (mol. $\mathrm{kg}_{\mathrm{w}}{ }^{-1}$ ) or adsorbed concentration (mol.kg-1 of solid) of species, $f$ is the activity coefficient of adsorbed species, and $\gamma$ is the activity coefficient of species in solution.

Since the activity coefficients of adsorbed species $f$ are not known, it is assumed that the ratio between these coefficients is constant. Thus, the apparent constants-called corrected selectivity coefficients $\mathrm{K}_{\mathrm{Na}^{+} / \mathrm{H}^{+}}^{* \mathrm{a}}$-are described as follows.

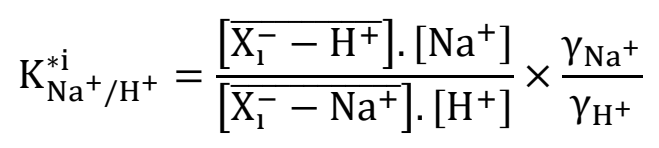

Each type of site $i$ is also described by its site concentration $\mathrm{SC}_{\mathrm{i}}$ in mol.kg-1 of solid, which is equal to the sum of all the adsorbed species concentrations:

$$
\mathrm{SC}_{\mathrm{i}}=\left[\overline{\left(\mathrm{X}_{1}^{-}\right)-\mathrm{H}^{+}}\right]+\left[\overline{\left(\mathrm{X}_{1}^{-}\right)-\mathrm{Na}^{+}}\right]
$$

Combining equations (B3) and (B4), the absorbed concentration of Na can be expressed as follows.

$$
[\overline{N a}]=\sum_{i}\left[\overline{X_{l}^{-}-N a^{+}}\right]=\sum_{i} \frac{\mathrm{SC}_{\mathrm{i}}}{1+\frac{\mathrm{K}_{N a^{+} / \mathrm{H}^{+}}^{* \mathrm{i}} \cdot 10^{-p H}}{\left[\mathrm{Na}^{+}\right] \cdot \gamma_{\mathrm{Na}^{+}}}}
$$

\section{B.2 Adsorption isotherms of trace elements}

To model the adsorption of trace elements $\mathrm{M}^{\mathrm{m}+}$ on Na-saturated exchangers, one has to account both for the $\mathrm{Na}^{+} / \mathrm{H}^{+}$reaction (B1) and the $\mathrm{M}^{\mathrm{m}+} / \mathrm{mH}^{+}$reaction,

$$
\overline{\left(\mathrm{X}_{1}^{-}\right)_{\mathrm{m}}-\mathrm{M}^{\mathrm{m}+}}+\mathrm{m} H^{+}=\mathrm{m} \overline{\mathrm{X}_{1}^{-}-\mathrm{H}^{+}}+\mathrm{M}^{\mathrm{m}+}
$$

with the corresponding corrected selectivity coefficient.

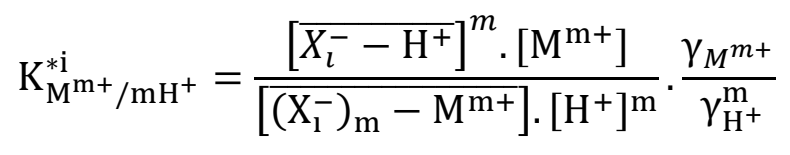

Complexation of cations in solution is taken into account and the concentration of available $\mathrm{M}^{\mathrm{m}+}$ is expressed as follows,

$$
\left[\mathrm{M}^{\mathrm{m}+}\right]=\frac{[\mathrm{M}]}{\alpha_{\mathrm{M}^{\mathrm{m}}+}}
$$

where $[\mathrm{M}]$ is the sum of all the M species concentration in solution and $\alpha_{\mathrm{M}^{\mathrm{m}}+}$ is the Ringböm (1963) coefficient. 
The equation of the site concentrations is written as follows.

$$
\mathrm{SC}_{\mathrm{i}}=\left[\overline{\left(\mathrm{X}_{1}^{-}\right)-\mathrm{H}^{+}}\right]+\left[\overline{\left(\mathrm{X}_{1}^{-}\right)-\mathrm{Na}^{+}}\right]+\mathrm{m}\left[\overline{\left(\mathrm{X}_{1}^{-}\right)_{\mathrm{m}}-\mathrm{M}^{\mathrm{m+}}}\right]
$$

Combining equations (B3), (B7), and (B9) the site concentration can be expressed as a

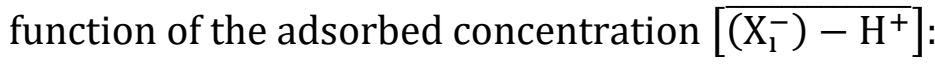

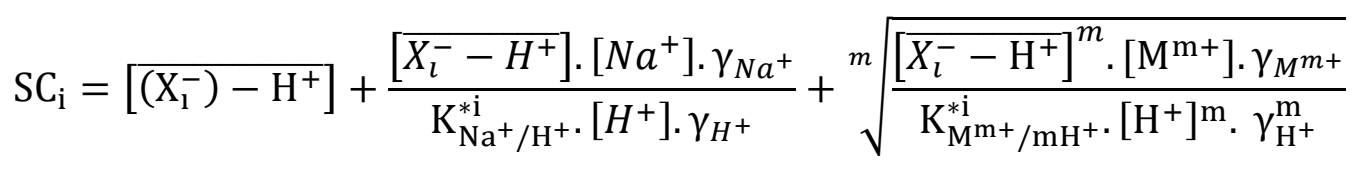

Solving this equation leads to determine $\left[\overline{\left(\mathrm{X}_{1}^{-}\right)-\mathrm{H}^{+}}\right]$then $\left[\overline{\left(\mathrm{X}_{1}^{-}\right)_{\mathrm{m}}-\mathrm{M}^{\mathrm{m}+}}\right]$ using equation (B7).

Finally, the distribution coefficient can be recalculated using:

$$
R_{D}=\frac{[\overline{\mathrm{M}}]}{[M]}
$$

\section{B.3 Transformation of selectivity coefficient from Missana and García-Gutiérrez (2007) in the multi-site ion exchange formalism}

Missana and García-Gutiérrez (2007) used the Gaines and Thomas (1953) formalism to express their selectivity coefficient. In this formalism, the selectivity coefficient is expressed as:

$$
\mathrm{K}_{2 \mathrm{Na}^{+} / S r^{2+}}^{*, \mathrm{GT}}=\frac{\left(N_{S r^{2+}}\right)}{\left(N_{N a^{+}}\right)^{2}} \cdot \frac{\left(a_{N a^{+}}\right)^{2}}{\left(a_{S r^{2+}}\right)}
$$

where $\left(N_{M^{m+}}\right)$ corresponds to the equivalent fractional occupancy on the exchanger and $a_{M^{m+}}$ is the activity of cations.

The expression of $\left(N_{M^{m+}}\right)$ is written:

$$
\left(N_{M^{m+}}\right)=\frac{m \cdot\left[\overline{\left.\left(X^{-}\right)_{m}-M^{m+}\right]}\right.}{\operatorname{CEC}}
$$

where $\left[\overline{\left(X^{-}\right)_{m}-M^{m+}}\right]$ is the adsorbed concentration of $\mathrm{M}$ in mmol.g-1 of solid and CEC is the cationic exchange capacity of the exchanger in mmol.g-1.

The selectivity coefficient can be re-expressed as follows. 


$$
\mathrm{K}_{2 \mathrm{Na}^{+} / S r^{2+}}^{*, \mathrm{TT}}=\frac{\left(\frac{2 \cdot\left[\overline{\left.\left(X^{-}\right)_{2}-S r^{2+}\right]}\right.}{C E C}\right) \cdot\left[\mathrm{Na}^{+}\right]^{2}}{\left(\frac{\left[\overline{X^{-}-N a^{+}}\right]}{C E C}\right)^{2} \cdot\left[\mathrm{Sr}^{2+}\right]} \cdot \frac{\gamma_{\mathrm{Na}^{+}}^{2}}{\gamma_{S r^{2+}}}
$$

Finally, combining with equation (B7) and considering the different adsorption sites $i$, this expression becomes:

$$
\mathrm{K}_{2 \mathrm{Na}^{+} / S r^{2+}}^{* \mathrm{i}, \mathrm{GT}}=2 \cdot \mathrm{SC}_{\mathrm{i}} \cdot \mathrm{K}_{2 \mathrm{Na}^{+} / S r^{2+}}^{* \mathrm{i}}
$$

